\title{
Stock Return Predictability: Risk Premium or Dividend Growth?
}

\section{David G. McMillan*}

Professor, Accounting and Finance Division, University of Stirling, UK

The standard stock return-dividend yield predictive regression remains one of the most researched equations in empirical finance and yet one of the most controversial, requiring further thought and work. At its simplest level, the predictive equation can be viewed as measuring the ability to predict returns, which in turn, would make for improved trading and asset allocation decisions. However, its greater economic significance lies in the view that the returns predictability equation helps us understand the dynamics of asset price movements and their causes. That is, the predictive regression and the asset pricing models that underlie the regression can allow us to elicit from them whether prices predominantly move due to changes in expected future cash flow (dividends) or changes in discount rates (risk premium). Cochrane [1] highlighted this essential issue, which is captured by the simple equation:

$$
d p_{t}=(\text { expected return })_{t}+(\text { expected dividend growth })_{t}+\text { error. }
$$

In running the predictive equation, where we use actual returns as a proxy for expected returns, we are often ruling out the ability of the dividend yield to predict expected dividend growth. Perhaps argued most strongly by Cochrane $[1,2]$ is the view that asset prices move according to changes in discount rates and not expected dividend growth. This seems to contradict our textbook view of the world, where it is changes in expected cash flow that moves market valuation and dividend yields. The evidence provided by Cochrane comes from US data.

This literature has developed many diverse paths, including those that present econometric evidence both for and against the existence of predictability $[3,4]$. However, the main economic content of the predictive equation is in trying to understand whether it is risk or cash flow that alters the dividend yield and hence, valuation. In an attempt to answer that question, Manzly et al. [5] augment the predictive equation with the stock price-consumption ratio. This, they argue, helps disentangle the offsetting effects of time-varying expected dividend growth on the expected returns and dividend yield relationship. More specifically, they argue that whether the price-dividend or priceconsumption ratio is more prominent in the predictive regression which depends on the mean reverting properties of dividend growth, such that slower mean reversion results in a stronger role for the dividend yield, they present evidence based on US data.

As noted above, it has been typical to rule out dividend growth predictability. However, this has recently been questioned. Chen [6] has reported evidence that the dividend yield may predict either returns or dividend growth but across different time periods. Similarly, Ang [7] provides substantial evidence of dividend growth predictability. Moreover, it has been argued that there exists time-variation in the predictive ability of the dividend yield [8]. Again the majority of this work focuses on US data.

Understanding the source of variation in equity valuation is important not only for asset pricing models but in understanding how markets work and how market participants behave. Thus, we are left with several unanswered questions. Is there evidence for predictability in stock returns or dividend growth? Of course, there can be evidence for both, but does predictability switch as suggested by Chen [6], in which case, why do certain periods predict returns and certain periods predict dividend growth? In other words, why is the risk premium more important in some periods and cash flow more important in other periods? Finally, in order to provide robust answers to these questions, they must be subjected to a wider range of data and hence market types, that currently with its heavy focus on the US.

\section{References}

1. Cochrane J (2010) Discount rates. Journal of Finance 66: 1047-1108.

2. Cochrane $\mathrm{J}$ (2008) The dog that did not bark: A defense of return predictability Rev. Financ. Stud 21: 1533-1575.

3. Campbell JY, Thompson SB (2008) 'Predicting excess stock returns out of sample: Can anything beat the historical average?' Rev. Financ. Stud 21: 5091531.

4. Goyal A, Welch I (2003) Predicting the equity premium with dividend ratios Management Science 49: 639-654.

5. Menzly L, Santos T, Veronesi P (2004) Understanding predictability. J Polit Econo 112: 1-47

6. Chen $L$ (2009) On the reversal of return and dividend growth predictability: A tale of two periods. Journal of Financial Economics 92: 128-151.

7. Ang A (2011) Predicting dividends in log-linear present value models. PacificBasin Finance Journal 20: 151-171.

8. Henkel SJ, Martin JS, Nardari F (2011) Time-varying short-horizon predictability Journal of Financial Economics 99: 560-580.
*Corresponding author: David G. McMillan, Professor, Accounting and Finance Division, University of Stirling, UK, E-mail: david.mcmillan@stir.ac.uk

Received July 26, 2012; Accepted July 28, 2012; Published July 31, 2012

Citation: McMillan DG (2013) Stock Return Predictability: Risk Premium or Dividend Growth? J Account Mark 2: e111. doi: 10.4172/2168-9601.1000e111

Copyright: () 2013 McMillan DG. This is an open-access article distributed under the terms of the Creative Commons Attribution License, which permits unrestricted use, distribution, and reproduction in any medium, provided the original author and source are credited. 